NBER WORKING PAPER SERIES

\title{
INTANGIBLE ASSETS, CORPORATE TAXES AND THE RELOCATION OF PHARMACEUTICAL ESTABLISHMENTS: THE CASE OF PUERTO RICO
}

\author{
Zadia M. Feliciano \\ Meng-Ting Chen \\ Working Paper 29107 \\ http://www.nber.org/papers/w29107 \\ NATIONAL BUREAU OF ECONOMIC RESEARCH \\ 1050 Massachusetts Avenue \\ Cambridge, MA 02138 \\ July 2021
}

Thanks to James R. Hines for comments on a preliminary version of this paper given at the American Economic Association Conference, 2020. Thanks to John Devereux, Matthew T. Cole, members of the University of North Dakota Economics Seminar, Queens College Economics Seminars and attendees of the Western Economic Association International Conference 2019 and 2021 for comments and suggestions. We thank the Puerto Rico division of the Quarterly Census of Employment and Wages for granting us permission to use the establishment level data. Luis Chacin provided excellent research assistance. This research was supported by Professional Staff Congress City University of New York grant TRADB-48-144. The views expressed herein are those of the authors and do not necessarily reflect the views of the National Bureau of Economic Research.

NBER working papers are circulated for discussion and comment purposes. They have not been peer-reviewed or been subject to the review by the NBER Board of Directors that accompanies official NBER publications.

(C) 2021 by Zadia M. Feliciano and Meng-Ting Chen. All rights reserved. Short sections of text, not to exceed two paragraphs, may be quoted without explicit permission provided that full credit, including $\odot$ notice, is given to the source. 
Intangible Assets, Corporate Taxes and the Relocation of Pharmaceutical Establishments:

The case of Puerto Rico

Zadia M. Feliciano and Meng-Ting Chen

NBER Working Paper No. 29107

July 2021

JEL No. F21,F23,H25,O14

\begin{abstract}
$\underline{\text { ABSTRACT }}$
Puerto Rico operated as a tax haven under U.S. Internal Revenue Code (IRC) Section 936. Firms in the pharmaceutical industry accounted for approximately $50 \%$ of tax credits awarded and $20 \%$ of employment under the program. The U.S. Congress eliminated the tax exemption program in 2006, creating a natural experiment on the elimination of corporate taxation of intangible assets. We use panel data on establishments from the Quarterly Census of Employment and Wages and a difference in difference methodology to measure the impact of the elimination of IRC Section 936 on pharmaceutical and medical devices using establishments with low, medium and high participation in the program as controls. Survival rates of all manufacturing establishments declined after the phaseout and elimination of the tax exemption program but pharmaceutical and medical devices establishments experienced an additional $6.9 \%$ decline. Approximately $50 \%$ of the $34 \%$ decline in pharmaceutical and medical devices establishments in Puerto Rico from 1995 to 2017 can be attributed to the elimination of IRC Section 936. Employment in pharmaceutical and medical devices establishments, which also declined by $34 \%$, decreased at the same rate as that of other industries. Plant closings accounted for most of the decline in their employment.
\end{abstract}

\title{
Zadia M. Feliciano
}

NBER

5 Hanover Square, 16th Floor

Suite 1602

New York, NY 10004-2630

zadia.feliciano@qc.cuny.edu

Meng-Ting Chen

The Graduate Center, CUNY

mchen2@gradcenter.cuny.edu

A data appendix is available at http://www.nber.org/data-appendix/w29107 


\section{Introduction}

Starting in the 1970s, the U.S. granted tax exemption to U.S. Corporations located in Puerto Rico through Internal Revenue Code (IRC) Section 936, which attracted large amounts of manufacturing investments and led to a large concentration of pharmaceutical establishments in the island (Alm, 2006). However, the tax exemption program was eliminated by the U.S. Congress in 2006. Evaluating the impact of the phaseout and elimination of this tax exemption program on survival rates and employment of manufacturing establishments can help us understand how pharmaceuticals respond to changes in corporate tax incentives and inform future policy. Moreover, it can help us understand the impact of the elimination of IRC Section 936 on Puerto Rico’s manufacturing industry and overall economic conditions. The government of Puerto Rico filed for bankruptcy similar to chapter 9 of the U.S. Bankruptcy Code in May 2017 (Scurria, and Gillers, 2017). ${ }^{1}$ The roots of the economic crisis in Puerto Rico have been traced in part to a large decline in the manufacturing industry, precipitated by the elimination of IRC Section 936 (Krueger, Teja and Wolf, 2015, Caraballo Cueto and Lara, 2017). The elimination of IRC Section 936 may be one of the most important factors responsible for the decline in the manufacturing industry in Puerto Rico (Feliciano, 2018).

Firms in the pharmaceutical and medical devices industry have substantial amounts of intangible assets, such as trademarks and patents. They are able to easily relocate in response to changes in corporate taxes because intangible assets do not have a real location. Countries with low corporate taxes, sometimes referred to as tax havens, have been able to attract firms with intangible assets. In recent years, many pharmaceutical firms have relocated to Ireland in part to

\footnotetext{
${ }^{1}$ Puerto Rico’s government owes more than $\$ 74$ billion dollars to creditors and 40 billion in pension liabilities (Farrant, 2017).
} 
benefit from their attractive $12.5 \%$ corporate tax rate. $^{2}$ Firms in the pharmaceutical industry accounted for approximately $50 \%$ of tax credits awarded and $20 \%$ of employment under IRC Section 936. The elimination of the tax exemption program is a natural experiment on corporate taxation of intangible assets because the change in the law was exogenous, enacted by the U.S. Congress despite opposition of the Puerto Rican government (Rohter, 1993). Puerto Rico is a U.S. territory and has no representation in the U.S. Congress. Thus, the policy change was an exogenous shock to industries in the island.

Our study is the first to use establishment level data to analyze the effects of the elimination of IRC Section 936 on survival rates and employment in the pharmaceuticals and medical devices industries. We created panel data using the Quarterly Census of Employment and Wages and used a difference in difference methodology to measure the impact of the elimination of IRC Section 936 using establishments with low, medium and high participation in the program as controls. Survival rates of all manufacturing establishment declined after the phaseout and elimination of the tax exemption program but pharmaceutical and medical devices establishments experienced an additional $6.9 \%$ decline. Approximately $50 \%$ of the $34 \%$ decline in pharmaceutical and medical devices establishments in Puerto Rico from 1995 to 2017 can be attributed to the elimination of IRC Section 936. Employment in pharmaceutical and medical devices establishments, which also declined by 34\% during this period, decreased at the same rate as that of other industries. Plant closings accounted for most of the decline in their employment.

\footnotetext{
${ }^{2}$ For example, in 2015, Medtronic PLC, a medical device company, acquired the Dublin based Covidien PLC and moved its headquarters from the U.S. to Ireland (Whalen, 2015).
} 


\section{Corporate Taxes and Multinational Firm Location}

Our paper provides new insights to an extensive literature on taxation and firm behavior. This literature has focused on the impact of taxation on profit shifting and location of multinationals. Hall and Jorgenson (1967) conducted seminal work with their study on the impact of taxes on the location of R\&D. Hines (1999) and Devereux (2007) surveyed the literature. Most of the empirical work has shown that taxes have a significant influence on firm location decision.

This literature has consistently found that taxation is a greater factor in the location of firms with intangible assets. Hines and Jaffe (2001) show that US multinationals locate innovative activities in areas that offer lower tax rates. Grubert and Altshuler (2007) find that multinational enterprises (MNEs) organize their activities and location in part with the goal of reducing their tax liabilities. Grubert (2003) finds that income from R\&D linked liabilities account for half of the income shifted from high-tax to low-tax countries. Dschinger and Riedel (2011) show that the largest proportion of MNE's intangible assets are held in the subsidiaries with the lowest corporate tax rate relative to other affiliates in the group. Griffith, Miller and O'Connel (2014) find taxes are an important factor in a firm's location of legal ownership of patents.

Research on tax havens has been an important part of this literature. Desai, Foley and Hines (2006) find that firms that are large, technology intensive and engage in substantial intrafirm trade, are more likely to have affiliates in tax havens. Moreover, firms that are high R\&D intensive have a greater demand for tax haven operations. Sigler, Martinus, Iacopini, and Derudder (2020) find that tax havens are more likely to be used by industries engaged in knowledge-intensive activities such as pharmaceuticals, biotechnology and semiconductors.

The literature on IRC Section 936 covers different aspects of the program. Grubert and Slemrod (1998) investigated income shifting by U.S. corporations operating under IRC Section 
936. They found that the operating capital and payroll of Puerto Rican affiliates would be more than two thirds lower in the absence of income shifting. Suárez Serrato (2018) investigated the impact of eliminating IRC Section 936 on firm investment and employ in the U.S. mainland. He finds that firms that operated under IRC Section 936 reduced global investment, increased their share of investment abroad and reduced US mainland employment by $6.7 \%$ compared to other firms. Garrett and Suárez Serrato (2019) find that firms taking advantage of IRC Section 936 had more assets, higher R\&D expenditures and were more profitable than other U.S. multinational. Ramirez (2021) finds that IRC Section 936 increased liquidity of Banks in Puerto Rico, which resulted in increasing lending to the commercial and industrial sectors of the island.

Feliciano and Green (2017) analyzed the effects of the phase out and elimination of IRC Section 936 on manufacturing employment and number of establishments in Puerto Rico using industry panel data. They find that the elimination of IRC Section 936 may be responsible for a $18.7 \%$ to $28.0 \%$ reduction in the number of manufacturing establishments in Puerto Rico, when using the states of Indiana, North Carolina, and Oregon as controls. Many newspaper articles from Puerto Rico have reported on plant closings and layoff in pharmaceutical establishments during years immediately after the elimination of IRC Section 936 (Ryan and Thurston, 2007). However,

there is no systematic analysis of the impact of the phaseout and elimination of IRC Section 936 on survival rates and employment in the Puerto Rican manufacturing sector using establishment level data.

\section{Puerto Rican History and IRC Section 936}

Puerto Rico became a U.S. colony in 1898 after the Spanish American War. According to Devereux (2019), Puerto Rico’s GDP per capita grew at 2.5 percent per year from 1900 to 1940 
while under U.S. colonial rule, when the government focused on infrastructure, education, and healthcare. The sugar industry and foreign firms (mostly from the U.S. mainland) were part of the development strategy. The New Deal brought important changes. It introduced new social programs and increased transfers from the U.S. mainland to the island. Moreover, starting with the appointment of Rexford Tugwell as governor in 1941, economic policy focused on fostering industrialization by establishing state owned enterprises, in cement, glass, shoes, paper and clay products. The Puerto Rico Industrial Development Company, the Puerto Rico Planning Board, and the Government Development Bank were created, and played a central role in the development of the island for many years. In 1949, Luis Muñoz Marín became the first elected Puerto Rican governor. After Operation Bootstrap was established during the 1940s, the island grew at exceptionally fast rates until the early 1970s. Real GDP per capita increased at a rate of 5.3 percent between 1950 and 1974.

U.S. corporations doing business in a U.S. possession (territory) received tax exemptions starting with the Revenue Act of $1921 .^{3}$ This legislation made Puerto Rico a tax heaven. The primary purpose of the possessions tax credit was to encourage U.S. corporations to invest and conduct significant business in U.S. territories. (Miller, 1999). The 1921 legislation provided an exemption from taxation for all income derived from sources outside the United States if certain conditions were met: the corporation had to derive 80 percent or more of its gross income from U.S. possessions and 50 percent or more of its gross income from the active conduct of a trade or business in the possessions (Holik, 2009). Over time, there were changes to the rules under which U.S. possessions corporations could get tax credits.

\footnotetext{
${ }^{3}$ U.S. possessions include Puerto Rico, the U.S. Virgin Islands, Guam, American Somoa and the Commonwealth of the Marian Islands.
} 
IRC Section 936 was established by the Tax Reform Act of 1976. The new law limited tax credit only to income derived from the active conduct of a trade or business in a possession and qualified possessions source investment income. Legislations in the 1980s put limits on tax credits given to U.S. possessions corporations. Under the original IRC Section 936, U.S. parent corporations could deduct research and development costs relative to an intangible asset and transfer the intangible asset to a related U.S. possessions corporation, where the resulting income would qualify for the possessions tax credit. The Tax Equity and Fiscal Responsibility Act of 1982 made possessions corporation's income from intangible assets taxable to the U.S. shareholders of the U.S. possessions corporation. However, a U.S. possessions corporation could get the tax credit on intangible assets if it demonstrated a significant business presence in the possession, by meeting either a direct labor test or a value-added test with respect to a specific product or type of service. Corporations could then choose to allocate income attributable to that product or service between the U.S. shareholders and the possessions corporations using either a cost-sharing or profit split method. In addition, the 1982 Act increased the percentage of gross income that a possessions corporation must earn from the active conduct of a trade or business in a U.S. possession in order to qualify for tax credits from 50 to 65 . The Tax Reform Act of 1986 further increased this percentage to 75 (Holik, 2009).

Legislations in the early 1990s continued to restrict tax credits under IRC Section 936. The Omnibus Budget Reconciliation Act of 1993 required corporations to separate their possessions income and credit computations into active and passive components. Passive income, possessions source investment income, continued to have unrestricted credit but the possessions credit derived from active income was subject to a limitation computed under either the percentage limitation or economic-activity limitation (Holik, 2009). 
While IRC Section 936 applied to all territories, most U.S. possessions corporations located in Puerto Rico. In 2005, 98.8\% of tax credits awarded under IRC Section 936 were given to U.S. possessions corporations located in Puerto Rico. Moreover, most IRC Section 936 corporations were in manufacturing, accounting for 69\% of tax credits in 2005 (Holik, 2009). IRC Section 936 made Puerto Rico an attractive location for U.S. manufacturing corporations, granting them tax exemption from income originating from the U.S. territory. While Puerto Rico has the advantage of lower wages, it has relatively high energy and transportation costs compared to U.S. mainland locations. The tax exemption program was a very important factor in the growth of manufacturing establishments in the island, especially pharmaceuticals.

In addition to the tax benefits from IRC Section 936, the Puerto Rican corporate tax code gave incentives to U.S. corporations to locate subsidiaries in the island. Puerto Rican tax law allowed a subsidiary, more than $80 \%$ owned by a foreign entity, to deduct $100 \%$ of the dividends paid to its parent. As a result, U.S. mainland subsidiaries located in Puerto Rico did not have corporate income tax liabilities as long as their profits were distributed as dividends (Greenberg and Ekins, 2015). IRC Section 936 corporations could repatriate income to their U.S. parents free of U.S. taxes, however, if their income was repatriated in the year it was earned, corporations had to pay a $10 \%$ Puerto Rican tollgate tax. To avoid the toll gate tax, corporations could invest their income for a period of time in eligible activities, including deposits in financial institutions authorized to receive IRC Section 936 funds (General Accounting Office, 1993). The liquidity infusion from the 936 funds into Puerto Rico's banking system was large, peaking at over $75 \%$ of GDP in the mid 1980s (Ramirez, 2021).

Puerto Rico's statutory corporate income tax rate is $20 \%$, with a progressive corporate income surtax that caps at $19 \%$ after $\$ 275,000$ of income. However, even though Puerto Rico’s 
top marginal income tax for corporations is 39\%, similar to corporate income tax rates in the U.S. mainland, in practice, few corporations pay 39\%, because Puerto Rico gives tax breaks to firms in specific industries to promote economic growth. (Greenberg and Ekins, 2015). It is common for firms to pay $0-4 \%$ on their profits for their first 15 years, and many of these tax benefits can be renewed. Moreover, Puerto Rico offers credits and exemptions from income and excise taxes during and after the construction phase (Krueger, Teja and Wolf, 2015).

Opposition to IRC Section 936 grew in the U.S. Congress because of the perception that job creating benefits of the program did not justify the loss of U.S. tax revenues. Many IRC Sections 936 corporations shifted intangible assets to the island to increase the amount of income that would qualify for tax exemption (Hexner and Jenkins, 1995). With the Small Business and Job Protection Act of 1996, the U.S. Congress eliminated IRC Section 936 beginning on tax years after December 31 ${ }^{\text {st }}$, 1995. No new corporations were given tax credits. However, a phaseout period of 10 years was given to existing U.S. possessions corporation. They could claim reduced tax credits from active income using the percentage or economic activity limitations through taxable years before January 1, 2006 (Holik, 2009). The loss of IRC Section 936 represented a large increase in corporate taxes for most U.S. corporations located in the island, and made Puerto Rico a less attractive business location.

Statistics on IRC Section 936 corporations for years 1983 to 2005 are shown in figure 1. The amount of tax credits given to corporations peaked in 1993 at 6.98 billion (2015 USD). The number of corporations claiming credits declined between 1983 and 1993, from 553 to 395. Thus, some establishments were closing in the island due to reasons unrelated to the phaseout and elimination of IRC Section 936. However, the decline in the number of IRC Section 936 
corporations accelerated after 1995, the start of the 10-year phaseout period. After 2005, there are no IRC Section 936 corporations since the tax program was eliminated.

Table 1 shows tax credits given to IRC Section 936 corporations by industry for years 1983, 1989 and 1993. Two industry groups accounted for approximately $70 \%$ of tax credits: pharmaceuticals (50\%), and electronic and electric equipment (20\%). Moreover, pharmaceuticals by far received the largest amount of tax credits per employee; in 1993 pharmaceuticals received \$120,343 (2015 USD) of credits per employee which is much higher than any industry including electrical and electronic equipment which received its highest tax credit per employee that year at \$75, 455 (2015 USD). This supports the view that firms with large amounts intangible assets, as is the case with pharmaceuticals, benefited the most from IRC Section 936. Employment in IRC Section 936 corporations increased from 88,579 in 1983 to 109,598 in 1993. During this period, employment in pharmaceuticals increased from 13,149 to 22,026 and percent of employment in the industry increased from $15 \%$ to $20 \%{ }^{4}$

The large presence of U.S. pharmaceuticals in Puerto Rico under IRC Section 936 can also be illustrated by the type of drugs produced, show in table 2. According to a General Accounting Office report (GAO, 1992), 17 of the 21 most prescribed drugs in the United States in 1990 were authorized for manufacture in the island. Moreover, seven pharmaceutical corporations were authorized to manufacture two or more of the 35 most prescribed U.S. drugs. Table 3 shows a list of pharmaceutical firms operating in Puerto Rico from the Book of Lists, a business-to-business directory of the most important firms in the island, published by Caribbean Business from 1990 to

\footnotetext{
4 The increase in pharmaceutical employment during this period may be due in part to the Tax Equity and Fiscal Responsibility Act of 1982 and the Tax Reform Act of 1986, discussed earlier. These legislations increased the percent of gross income that a possessions corporation must earn from the active conduct of a trade or business in a U.S. possession from 50 to 75 .
} 
2017. The list includes affiliates of some of the largest U.S. and foreign owned pharmaceutical and medical devices corporations. Seventy seven percent of firms were established in Puerto Rico before 1976, when IRC Section 936 was created. After IRC Section 936 was abolished in 2006, only one new pharmaceutical corporation was added to the directory, Neolpharma Inc., a Mexican affiliate that began operations by purchasing assets of a plant owned by Pfizer in October 2012 and specializes in the production of generic drugs.

\section{Tax Holiday Model}

The tax holiday model developed by Eric Bond (1981) helps us understand theoretical predictions of the impact of eliminating IRC Section 936. The model is an extension of Jorgenson (1963) cost of capital model. Bond developed the tax holidays model to illustrate the impact of an industrial tax exemption program in Puerto Rico in 1949 A tax holiday is a subsidy to a particular characteristic of capital goods and will result in substitution by firms towards this characteristic. The subsidy creates a distortion arising from the fact that too much of the good is produced, creating too much of the subsidized characteristic.

The corporate income tax affects the behavior of firms through its impact on the rental cost of capital. Capital goods are infinitely lived but they wear out at an exogenous rate $\delta$ each period. If there is no difference in the productivity of capital of different periods, then a new machine that is s years old will be equivalent to $e^{-\delta s}$ units of new machinery.

$\mathrm{R}(\mathrm{s})$ represents the quasi-rent earned on a unit of machinery at time $\mathrm{s}$. The present value of the returns from a machine purchased at time 0 will be:

$$
V_{0}=\int_{0}^{N}\left(1-t^{\prime}\right) R(s) e^{-(r+\delta) s} d s+\int_{N}^{\infty}(1-t) R(s) e^{-(r+\delta) s} d s
$$


where $r$ is the market rate of interest (after taxes), $t$ is the corporate tax rate, $t^{\prime}$ is the tax rate during the tax holiday, and $\mathrm{N}$ is the length of time of the tax holiday. Time 0 is the start of operations of the firm, since the firm gets the low tax rate only until it reaches age $\mathrm{N}$. The firm will choose to purchase a unit of capital as long as the present value of the returns is at least equal to the price of a unit of capital. Normalizing, so that the price of a unit of capital good is 1 , the capital good will be purchased as long as $V_{0} \geq 1$. The model predicts that firms that face an expiration of the tax holiday will liquidate when the tax holiday expires.

Bond's model does not predict that all manufacturing establishments will liquidate, only the ones that were attracted to the location because of the tax holiday. In the case of IRC Section 936, firms do not need to reach a specific age when they lose the tax holiday but they face the end of the tax holiday in the future after a specific number of years. Bond's model predicts many, but not all, of the IRC Section 936 establishments will close once the tax holiday ends.

\section{Firm Level Data}

We use establishment level data from the Quarterly Census of Employment and Wages (QCEW) for Puerto Rico, 1990 to 2017 to create a panel of manufacturing establishments. The Quarterly Census of Employment and Wages (QCEW) program is a division of the U.S. Bureau of Labor Statistics. They collect data on employment and wages from employers covering more than 95 percent of U.S. jobs from all states and U.S. territories. Data from the QCEW contains most firms and their establishments in Puerto Rico.

Our panel consists of 5,616 establishments in manufacturing industries for 28 years, 19902017. ${ }^{5}$ It is an unbalanced panel since establishments opened and closed during this period. Each

\footnotetext{
${ }^{5}$ Establishment observations with missing information were dropped from the sample.
} 
establishment has a 4-digit Standard Industrial Classification (SIC) code. ${ }^{6}$ We group establishments into four groups: pharmaceutical and medical devices, low 936, medium 936, and high 936. Establishments were grouped based on their industries percent of production in section 936 firms: 0 to 20 in low 936, 21to 80 in medium 936 and 81 to 100 in high 936. Pharmaceutical and medical devices establishments had 99.6\% of production in IRC Section 936 firms, similar to those in the high 936 group. Our panel includes the following number of establishments in each group: 342 pharmaceutical and medical devices, 1,896 low 936, 2,106 medium 936, 1,272 high 936. Employment was calculated as the monthly average in quarter two of each year, April, May and June.

\section{Methodology}

We use a difference in difference methodology to estimate the impact of the elimination of IRC Section 936 on survival rates and employment in pharmaceutical and medical devices establishments in Puerto Rico. The elimination of Section 936 was a policy decided and put in place by the U.S. Congress, an exogenous shock to establishments in the island.

Pharmaceutical and medical devices establishments are the experiment group since they were most affected by the elimination of IRC Section 936 due to their substantial ownership of intangible assets, receiving most of the tax credits and the largest tax credit per worker. We use three alternative control groups composed of manufacturing establishments in industries with different exposure to IRC Section 936: low, medium, and high. ${ }^{7}$

\footnotetext{
${ }^{6}$ We use the NAICS to SIC concordance from the U.S. Census to convert all industrial classifications to SIC. The Puerto Rico QCEW uses SIC classifications until 1997 and NAICS classifications after that year. https://www.census.gov/eos/www/naics/concordances/concordances.html.

${ }^{7}$ Please refer to table 4 for degree of participation of industries in each group in IRC Section 936.
} 
To estimate the impact of IRC Section 936 on survival rates of pharmaceutical and medical devices establishments, we use a two-step procedure. First, we estimate the following probit survival rate model:

$$
\operatorname{Pr}\left(\text { survive }_{i j t}\right)=\beta_{1} \text { llemp }_{i j t-1}+\beta_{2} \text { age }_{i j t}+\beta_{3} \text { SJmetro }_{i j t}+\beta_{4} \text { large }_{i j t}+\gamma_{j}+\delta_{t}+\omega_{i j t}(1)
$$

The subscript i represents an establishment, $\mathrm{j}$ an industry and t a year. The variable survive $_{i j t}$ equals 1 if establishment $\mathrm{i}$ in industry $\mathrm{j}$ is in business in Puerto Rico in year $\mathrm{t}$ and zero otherwise. The variable $l l e m p_{i j t-1}$ is the inverse hyperbolic sine function of lagged employment of establishment $\mathrm{i}$ in industry $\mathrm{j}$ and year $\mathrm{t}^{8}{ }^{\mathrm{T}}$ The variable age refers to number of years since the opening of the establishment. The variable SJmetro $_{i j t}$ equals 1 if the establishment is located in the San Juan Metropolitan Area, the capital and largest city in Puerto Rico, and zero otherwise. ${ }^{9}$ The variable $\operatorname{larg} e_{i j t}$ equals 1 if the establishment has more than 100 employees and zero otherwise. The variable $\gamma_{j}$ is an industry fixed effect at the 4-digit SIC level, $\delta_{t}$ is a year fixed effect and $\omega_{i j t}$ is a random error. We use cluster standard errors by establishment id to correct for heteroskedasticity.

In the second step, we predict the survival rate of each establishment in a given year based on equation (1). We then use the predicted survival rate of each establishment to estimate the impact of the elimination of IRC Section 936 on survival rates of establishments in the pharmaceutical and medical devices industry compared to our control groups. Our second-stage probit survival rate regression is shown in (2).

\footnotetext{
${ }^{8}$ The inverse hyperbolic sine is similar to the log function but has the benefit of being defined at zero (Burbidge, Magee and Robb, 1988). The function is $\operatorname{arcsinh}(\mathrm{x})=\ln \left(x+\sqrt{\left(\mathrm{x}^{2}+1\right)}\right)$. When using the inverse hyperbolic sine function, the estimated coefficients may need to be transformed prior to interpreting them as percentage changes (Bellemare and Wichman, 2020).

${ }^{9}$ The San Juan metropolitan is home to approximately $25 \%$ of the population and includes the municipalities of San Juan, Bayamón, Carolina, Cataño, Guaynabo, and Trujillo Alto.
} 
$\operatorname{Pr}\left(\right.$ survival $\left._{i j t}\right)=\alpha_{i}+\beta_{1}$ llemp $_{i j t-1}+\beta_{2}$ age $_{i j t}+\beta_{3}$ SJmetro $_{i j t}+\beta_{4}$ large $_{i j t}+\beta_{5}$ 936phaseout $_{t}+$ $\beta_{6}{\text { after } 936_{t}+\beta_{7} \text { pharma }_{j} \times 936 \text { phaseout }}_{t}+\beta_{8}$ pharma $_{j} \times$ after $936_{t}+\delta_{t}+\varepsilon_{i j t}(2)$

The variable surviv $a_{i j t}$ is the predicted survival rate for establishment $\mathrm{i}$ in industry $\mathrm{j}$ and year $\mathrm{t}$. The term $\alpha_{i}$ is an establishment specific intercept. Independent variables include llemp, age, SJmetro and large, also included in equation (1). To capture the impact of IRC Section 936, we include the variable 936 phaseout $_{t}$ which equals 1 for phaseout years, 1996 to 2005, and zero otherwise, and after $936_{t}$ which equals 1 for years after the elimination of the program, 2006 to 2017. The variable pharma $_{j}$ equals 1 if establishment $i$ is in the pharmaceutical and medical devices industry and zero otherwise. The coefficient $\beta_{7}$ on the interaction term $p h a r m a_{j} \times$ 936 phaseout $_{t}$ measures differences in the survival rate of pharmaceutical and medical devices establishments and the control group during the phaseout of IRC Section 936. The coefficient $\beta_{8}$ on the interaction term pharma $_{j} \times$ after $936_{t}$ measures differences in the survival rate of pharmaceutical and medical devices establishments and the control group after the elimination of IRC Section 936. The term $\delta_{t}$ is a year fixed effect and $\varepsilon_{i j t}$ is a random error. We use clustered standard errors by establishment id to correct for heteroskedasticity.

To analyze how the elimination of IRC Section 936 affected employment in pharmaceutical and medical devices establishments, we estimate the following fixed effects equation:

lemp $_{i j t}=\alpha_{i}+\beta_{1}$ survlval $_{i j t}+\beta_{2}$ SJmetro $_{i j t}+\beta_{3}$ large $_{i j t}+\beta_{4} 936$ phaseout $_{t}+\beta_{5}{\text { after } 936_{t}}_{t}+$

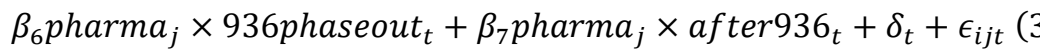

The variable $l e m p_{i j t}$ is the inverse hyperbolic sine function of employment of establishment $\mathrm{i}$ in industry $\mathrm{j}$ and year $\mathrm{t}$. Other variables are the same as in equation (2). We added to the equation our estimated probability of survival, survival $l_{i j t}$, to control for the fact many manufacturing 
establishments closed during our sample period. The coefficients $\beta_{6}$ and $\beta_{7}$ show differences in employment in pharmaceutical and medical devices establishments and the control groups during the phaseout and elimination of IRC Section 936. The term $\delta_{t}$ is a year fixed effect and $\epsilon_{i j t}$ is a random error. All regressions were estimated using robust standard errors.

\section{Statistical Analysis}

Graphs of trends in manufacturing employment show Puerto Rico experienced a decline in manufacturing employment that coincides with the phaseout and elimination of IRC Section 936. Figure 2 shows trends in Manufacturing employment in Puerto Rico (left axis) and the U.S. mainland (right axis). Puerto Rico’s manufacturing employment peaked in 1995, the last year before the phaseout of IRC Section 936. Moreover, while employment in Puerto Rico followed trends similar to those of the U.S. mainland from 1990 to 2005. After 2005, when IRC Section 936 ended, Puerto Rico experienced a rapid decline in manufacturing employment which contrasts with the U.S. mainland where manufacturing employment became stagnant but did not undergo large declines.

Figure 3 shows trends in the number of establishments in the pharmaceutical and medical devices industry in Puerto Rico along with those in the U.S. mainland. ${ }^{10}$ In Puerto Rico, the number peaked in 2007, a year after the elimination of IRC Section 936, followed by a rapid decline. From 1995, the year before the phaseout period of IRC Section 936, until 2017, the number of establishments declined by 34.2\% in Puerto Rico, from 184 to 121 . This contrasts with the U.S. mainland which saw a $6.3 \%$ increase in the number of establishments during the same period. Statistics on employment in the pharmaceutical and medical devices industry in

\footnotetext{
${ }^{10}$ Pharmaceutical and Medical Devices refer to NAICS 325 Pharmaceutical and Medicine Manufacturing and NAICS 3391 Medical Equipment and Supplies Manufacturing.
} 
Puerto Rico along with the U.S. mainland are shown in figure 4. Employment in Puerto Rico peaked in 1995, followed by a rapid decline until 2017. The number of jobs declined from 37,787 to 24,867 , a $34.1 \%$ fall. This contrast with an $11.0 \%$ increase in employment in the U.S. mainland during the same period.

We decompose changes in employment in the pharmaceutical and medical devices industry using the following equation:

$$
\Delta e m p_{t}=\underbrace{n_{t-1} \Delta \overline{e m p}_{t}}_{\text {within }}+\underbrace{\overline{\operatorname{emp}}_{t} \Delta \mathrm{n}_{\mathrm{t}-1}}_{\text {between }}
$$

The term emp refers to employment, $\overline{e m p}$ refers to average employment per establishment, $n$ refers to the number of establishments and t refers to a given year. The within term is the change in employment due to changes in the average employment within establishments. The between term refers to changes in employment due to changes in the number of establishments, due to openings or closings. Figure 5 shows within and between changes in employment using our establishment data. Notice that from 2000 to 2003, during the phaseout of IRC Section 936, overall employment grew due to increases in employment within establishments. This may be due to added restrictions put on IRC Section 936 corporations requiring them to meet a tougher direct labor test or value-added test in order to be eligible for tax credits. At the same time, this period saw decreasing employment due to plant closings. Plant closings continued until 2006, with a temporary increase in 2007 and a continued decline until 2015. From 2004 to 2005, the last two years of IRC Section 936, employment dropped due to both plant closings and declines in average employment within establishments. Most of the decline in employment from 1990 to 2017 was due to plant closings.

Figure 6 shows trends in employment for the four industry groups in our sample: pharmaceutical and medical devices, low 936, medium 936 and high 936. Employment trends 
for most manufacturing groups are similar before the phaseout of IRC Section 936, 1990 to 1995, and declined during the years of the phaseout and elimination of the tax exemption program. The exception is medium 936, which appears to already be in decline in the 1990s. This may be due to the fact that the medium 936 group includes apparels and other textile products (SIC 23). This industry was under increasing import competition and in decline in the U.S. since the 1970s even though it was protected under the Multi-Fiber Arrangement (Adkisson, 2002). ${ }^{11}$ While we use all three control groups in our analysis, the medium 936 group is less reliable.

To analyze the impact of the elimination of IRC Section 936 on the survival rate of pharmaceutical and medical devices establishments in Puerto Rico, we estimate the probit survival equation shown in (1). Results from this first stage regression are in the appendix. Using this model, we predict survival rates for all establishments. Figure 7 shows mean predicted survival rate for establishments in all manufacturing groups. Survival rates for all groups declined after 1997, two years after the start of the 10-year phaseout of IRC Section 936. The lowest survival rate for manufacturing establishments in all industries occurred in 2007, a year after the elimination of IRC Section 936. Moreover, pharmaceutical and medical devices establishments experienced a larger decline in survival rates during years preceding and following the elimination of IRC Section 936.

Table 5 shows our estimates of the impact of the phaseout and elimination of IRC Section 936 on predicted survival rates of establishments in the pharmaceutical and medical devices industry based on equation (2) using low 936, medium 936 and high 936 as control groups. We have added a fourth group, non-pharma manufacturing, which includes establishments from all

\footnotetext{
${ }^{11}$ The Multi-Fiber Arrangement (MFA) imposed quotas on the amount developing countries could export to developed countries. It took effect in 1974 and was phased out between 1995 and 2004.
} 
three control groups. These regressions show age of establishment does not significantly affect survival rates except in regressions with the control low 936, which is significant at the $1 \%$ level and shows older establishments have a higher survival rate. Survival rates are higher for firms in the San Juan Metro Area, significant at the 5\% or higher when using all control groups except for low 936. Survival rates are lower for large establishments, significant at the $1 \%$ level in all regressions regardless of control group. Since all regressions control for lag employment, which is another measure of size of establishment, and is positively related to survival rates and significant at the $1 \%$ level, the negative coefficient on large establishments appears to indicate a more moderate impact of size of establishment on survival rates.

Survival rates are lower during the 10-year phaseout period of IRC section 936 when using medium 936, and non-pharma as controls, with 5\% and 10\% significance level respectively. All regressions show a decline in survival rates after the elimination of IRC Section 936, significant at the $1 \%$ level, providing evidence of the negative impact eliminating IRC Section 936 had on survival of manufacturing establishments across all categories. The coefficient on the interaction term between the phaseout period, and pharmaceutical and medical devices variables is negative and significant at the $1 \%$ level in all regressions regardless of control group. The interaction term between the after 936, and pharmaceutical and medical devices variables is also negative and significant at the 5\% level in regressions using low 936 and medium 936 as control groups and at the $10 \%$ level when using non-pharma as the control group. These results provide evidence that the phaseout and elimination of IRC Section 936 caused greater plant closures in the pharmaceutical and medical devices industry than in any other manufacturing industry group.

Table 6 shows marginal average probabilities from our probit regressions in table 5. After adding all coefficients on the interaction terms of the 10-year phaseout and after 936 variables with 
pharma, we estimate that the survival rate of pharmaceutical and medical devices establishments declined by .095 relative to low 936, .065 relative to medium 936, .054 relative to high 936 , and .069 relative to non-pharma during the phaseout and elimination of IRC Section 936. When adding all coefficients related to IRC Section 936, we estimate the overall impact of section 936 on survival rates of pharmaceutical and medical devices is -.162 when using non-pharma controls. Our estimates explain approximately $50 \%$ of the $34 \%$ decline in the number of pharmaceutical and medical devices establishments in Puerto Rico from 1995 to 2017.

Table 7 shows our estimates of the impact of the phaseout and elimination of Section 936 on employment of establishments in the pharmaceutical and medical devices industry based on equation (3) using our control groups. These regressions show a negative and significant coefficient on the IRC Section 936 phaseout variable at the 5\% level in regressions using high 936 as the control and at the $10 \%$ level when using non-pharma as the control. The coefficient on the after 936 variable is negative and significant at the $1 \%$ level in all regressions, regardless of control group. The estimated coefficient varies depending on the control group, ranging from -.12 when using low 936 to -.20 when using high 936 . This provides evidence of the negative impact the elimination of IRC Section 936 had on manufacturing employment in all categories. We find no evidence that establishments in the pharmaceutical and medical devices industries decreased employment by more than establishments in the control groups. Coefficients on interaction terms between pharma and the phaseout variable as well as the after 936 variable are insignificant.

The employment and survival rate results indicate that establishment in pharmaceutical and medical devices were more likely to close during the phaseout and elimination of IRC Section 936 but were not more likely to reduce employment when compared with other manufacturing establishments. 


\section{Robustness Checks}

We apply several robustness checks to our analysis. First, we check the validity of our control groups. For the difference in difference results to be reliable employment trends of establishments in the pharmaceutical and medical devices industry should be similar to those of the control groups prior to the phaseout and elimination of IRC Section 936. We analyzed pretrends of establishments in pharmaceutical and medical devices industries and the control groups testing the hypothesis of pre-trends for the years 1990 to 1994. Results are available in table 8. We cannot reject the hypothesis of pre-trends in the case of low 936, high 936 and non-pharma manufacturing. However, we reject the hypothesis of pre-trends in the case of medium 936. Thus, all controls are valid except for medium 936. This is not surprising as we discussed earlier because employment in the medium 936 group was declining prior to the phaseout and elimination of Section 936.

Second, we estimate survival rates and employment fixed effects regressions using yearly interactions with the pharmaceuticals and medical devices variable to determine if the yearly differentials are consistent with the hypothesis that the phaseout and elimination of IRC Section 936 caused greater harm to the pharmaceutical and medical devices industry. Figure 8 shows coefficients and 95\% confidence intervals from survival rate probit regressions with yearly interaction terms and non-pharma manufacturing as a control. The coefficients on the interaction term are negative and significantly at the 5\% level or higher in 2003, 2004, 2005 and 2007. These are a few years prior and after the elimination of IRC Section 936, confirming the elimination of the program resulted in more plant closures in the pharmaceutical and medical devices than other industries. Estimates using low 936, medium 936 and high 936 as control groups are similar. 
Figure 9 shows coefficients and 95\% confidence intervals from employment fixed effects regressions using yearly interaction terms and non-pharma manufacturing as a control. We find no employment differential between pharmaceutical and medical devices and non-pharma manufacturing establishments with the exception of 2014 when pharmaceutical and medical devices had a positive employment differential. Estimates from regressions using low 936, medium 936 and high 936 as control groups are similar.

\section{Conclusion}

Pharmaceutical corporations benefited the most from IRC Section 936. They received the largest amount of tax credits, approximately 50\%, and largest tax credit per employee, as high as $\$ 120,000$. They also experienced a disproportionate amount of plant closures as a result of the phaseout and elimination of the tax incentive program.

Survival rates of all manufacturing establishments declined during the phaseout and elimination of IRC Section 936 but pharmaceutical and medical devices establishments experienced the largest decline, $6.9 \%$ relative to non-pharma. Our results suggest that nearly $50 \%$ of the 34\% reduction in pharmaceutical and medical devices establishments in Puerto Rico between 1995 and 2017 can be attributed to the phaseout and elimination of IRC Section 936. Approximately 30 establishments with an estimated 6,000 employees closed in the pharmaceutical and medical devices industry due to the elimination of the tax incentive program. ${ }^{12}$

We found that controlling for survival rates, employment decreased in all manufacturing establishments by $18 \%$ during the phase out and elimination of IRC Section 936 . There is no

\footnotetext{
${ }^{12}$ Based on our probit estimates of a decline in survival rates of -.162 due to the elimination of IRC Section 936 (table 6), the number of establishments in 1995 and the average number of workers per establishments from 1995 to 2017 using QCEW public data.
} 
evidence that establishments in the pharmaceutical and medical devices industries reduced employment by more than other industries.

Our results are consistent with the Tax Holiday model developed by Eric Bond (1981), which predicts that at the end of a tax exemption program, in this case IRC Section 936, firms have an incentive to liquidate. They are also consistent with the literature on the importance of tax incentives on the location of firms with intangible assets.

The elimination of IRC Section 936 was a major factor in the decline of manufacturing establishments in Puerto Rico, responsible for a large number of plant closures in the pharmaceutical and medical devices industry. With the Covid-19 pandemic, calls to bring back the pharmaceutical and medical devices industry to Puerto Rico have increased due to political concerns about dependence on foreign countries for medical supplies (Cabranes, 2020). Efforts to bring back the pharmaceutical industry to Puerto Rico could be challenging due to a decline in its production efficiency (Ramcharran, 2011). This study provides strong evidence that taking away the corporate tax exemption program led to the decline of the industry in the island. 


\section{Bibliography}

Adkisson, Richard V. (2002). "Immigration and Regional Comparative Advantage in the Apparel Industry.” International Trade Journal, 16 (1), 1-31.

Alm, James (2006). “Assessing Puerto Rico’s Fiscal Policies,” in Susan Collins, Barry P. Bosworth and Miguel A. Soto-Class (Editors) The Economy of Puerto Rico: Restoring Growth (pp. 319-375). Brookings Institution Press.

Bellemare, Marc F. and Casey J. Wichman (2020). "Elasticities and the Inverse Hyperbolic Sine Transformation.” Oxford Bulletin of Economics and Statistics, 82(1), 50-61.

Bond, Eric (1981). “Tax Holidays and Industry Behavior.” The Review of Economics and Statistics 63 (1), pp. 88-95.

Cabranes, José A. (2020, May 20). “Bring the Drug Industry Back to Puerto Rico,” The Wall Street Journal. https://www.wsj.com/articles/bring-the-drug-industry-back-to-puerto-rico$\underline{11590015910}$

Caraballo Cueto, José and Juan Lara (2017). “Deindustrialization and Unsustainable Debt in Middle-Income Countries: The Case of Puerto Rico.” Journal of Globalization and Development, 8 (2), 1-11.

Caribbean Business, The Book of Lists, 1990-2017. Latin Media House, LLC, Guaynabo, Puerto Rico. www.caribbeanbusiness.com

Desai, Mihir A., C. Fritz Foley and James R. Hines (2006). “The demand for tax haven operations.” Journal of Public Economics 90 (3), 513-531.

Devereux, John (2019). “Arrested Development? Puerto Rico in an American Century.” Journal of Economic History, 79(3), 708-735.

Devereux, Michael P. (2007). "The impact of taxation on the location of capital, firms and profit: a survey of empirical evidence.” Oxford University Centre for Business Taxation, Working Paper 702.

Dischinger, Matthias and Nadine Riedel (2011). "Corporate taxes and the location of intangible assets within multinational firms.” Journal of Public Economics. 95 (7-8), 691-707.

Farrant, Jaime (2017, June 5). “4 Reasons Why Puerto Rico's 'Bankruptcy' Process Matters to U.S. Residents.” NBC News. https://www.nbcnews.com/news/latino/4-reasons-why-puerto-ricos-bankruptcy-process-matters-u-n766991

Feliciano, Zadia M. (2018). IRS Section 936 and the Decline of Puerto Rico's Manufacturing. Centro Journal 30(3), 30-42. 
Feliciano, Zadia M. and Andrew Green (2017). “US Multinationals in Puerto Rico and the Repeal of Section 936 Tax Exemption for U.S. Corporations.” NBER Working Paper 23681.

General Accounting Office (1993). "Puerto Rico and the Section 936 Tax Credit.” Report GGD93-109. GGD-93-109.

General Accounting Office (1992). "Pharmaceutical Industry Tax Benefits of Operating in Puerto Rico.” GGD-92-72BR.

Garrett, Daniel and Juan Carlos Suárez Serrato (2019). "How Elastic is the Demand for Tax Havens? Evidence from the US Possessions Corporations Tax Credit.” American Economic Association Papers and Proceedings 109, 493-499.

Greenberg, Scott and Gavin Ekins (2015, June 30). “Tax Policy Helped Create Puerto Rico’s Fiscal Crisis.” Tax Foundation. https://taxfoundation.org/tax-policy-helped-create-puerto-ricofiscal-crisis/

Griffith, Rachel, Helen Miller and Martin O’Connell (2014). “Ownership of intellectual property and corporate Taxation.” Journal of Public Economics 112, 12-23.

Grubert, Harry, (2003). “Intangible income, Intercompany Transactions, Income Shifting, and the Choice of Location.” National Tax Journal, 56 (1), 221-242.

Grubert, Harry and Rosanne Altshuler (2007). Corporate Taxes in the World Economy: Reforming the Taxation of Cross-Border Income. Departmental Working Papers 200626. Rutgers University, Department of Economics.

Grubert, Harry and Joel Slemrod (1998). “The Effect of Taxes on Investment and Income Shifting to Puerto Rico,” The Review of Economics and Statistics, 80(3), 365-373.

Hall, Robert E. and Dale W. Jorgenson, (1967). “Tax policy and investment behavior.” American Economic Review, 57, 391-414.

Hexner, Thomas J. and Glenn P. Jenkins (1995, January 16). "Puerto Rico and Section 936: A Costly Dependence.” Tax Notes. https://www.taxnotes.com/document-list/contributorsauthors/jenkins-glenn-p

Hines, James R. (1999). “Lessons from behavioral responses to taxation.” National Tax Journal, 52 (2), 305-322.

Hines, James R. and Adam B. Jaffe (2001). “International taxation and the location of inventive activity” James Hines (editor) International Taxation and Multinational Activity (pp. 201-226). NBER Conference Report series. University of Chicago Press.

Holik, Daniel S. (2009). “US Possessions Corporations, 2005.” Statistics of Income (SOI) Bulletin, Spring, 28(4), 92-105. 
Krueger, Anne O., Ranjit Teja and Andrew Wolf (2015). "Puerto Rico - A Way Forward,” Executive Summary. Report to the Government Development Bank of Puerto Rico.

Miller, Randy (1999). “U.S. Possessions Corporations, 1995.” Statistics of Income (SOI) Bulletin, Summer, 19(1), 168-184.

Puerto Rico Planning Board (1993). "Impacto de las Firmas 936 sobre la Economia de Puerto Rico.” Office of the Governor.

Ramcharran, Harri (2011). “The pharmaceutical industry of Puerto Rico: Ramifications of global competition.” Journal of Policy Modeling, 33(3), 395-406.

Ramirez, Carlos D. (2021). “The Real Effects of liquidity: Puerto Rico as a natural experiment.” Economic Inquiry, 59(3), 1172-1191

Rohter, Larry (1993, May 10). "Puerto Rico Fighting to Keep Its Tax Breaks for Businesses," New York Times. https://www.nytimes.com/1993/05/10/business/puerto-rico-fighting-to-keepits-tax-breaks-for-businesses.html

Ryan, Frances and Lawson D. Thurston (2007, January 25). “12,974 jobs lost in past 24 months,” Caribbean Business.

Scurria, Andrew and Heather Gillers. (2017, May 4th). "Puerto Rico to Square Off with Creditors,” Wall Street Journal.

Sigler, Thomas, Kirsten Martinus, Iacopo Iacopini, and Ben Derudder (2020). "The role of tax havens and offshore financial centres in shaping corporate geographies: an industry sector perspective.” Regional Studies, 54(5), 621-633.

Suárez Serrato, Juan Carlos (2018). “Unintended Consequences of Eliminating Tax Havens.” NBER Working Paper 24850.

Whalen, Jeanne (2015, August 25). “Medtronic to Buy California Startup Twelve Inc.“ Wall Street Journal. https://www.wsj.com/articles/medtronic-to-buy-privately-held-twelve-inc1440510504 
Figure 1: Number of IRC Section 936 Corporations and Credits Claimed, 1983-1995

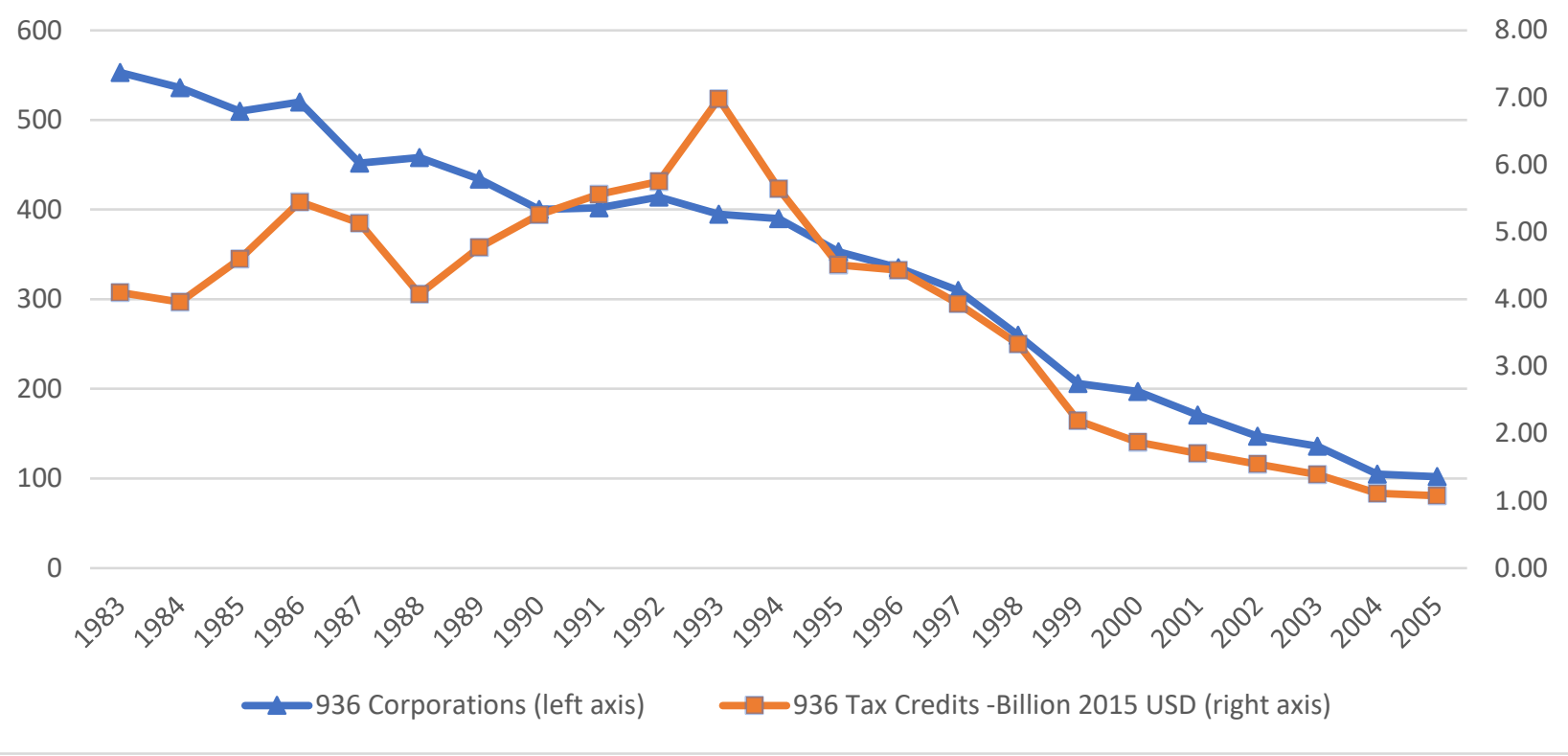

Source: Author’s graph. Data from IRS Statistics of Income Bulletin (Holik 2009).

Figure 2: Manufacturing Employment

$P R$ and US

(thousands of workers)

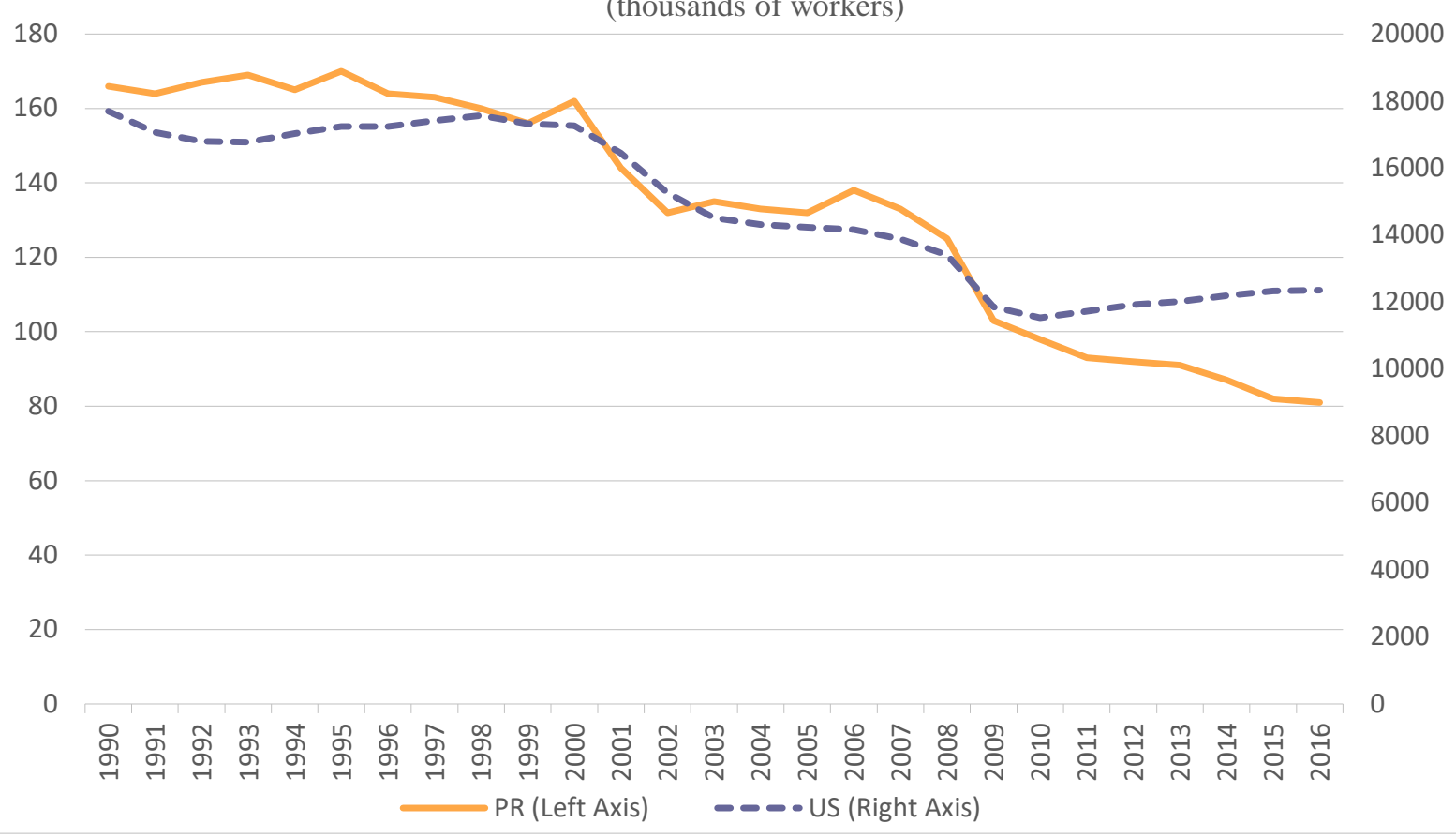

Source: Authors' graph. QCEW public data 
Figure 3: Establishments Pharmaceutical \& Medical Devices PR and US

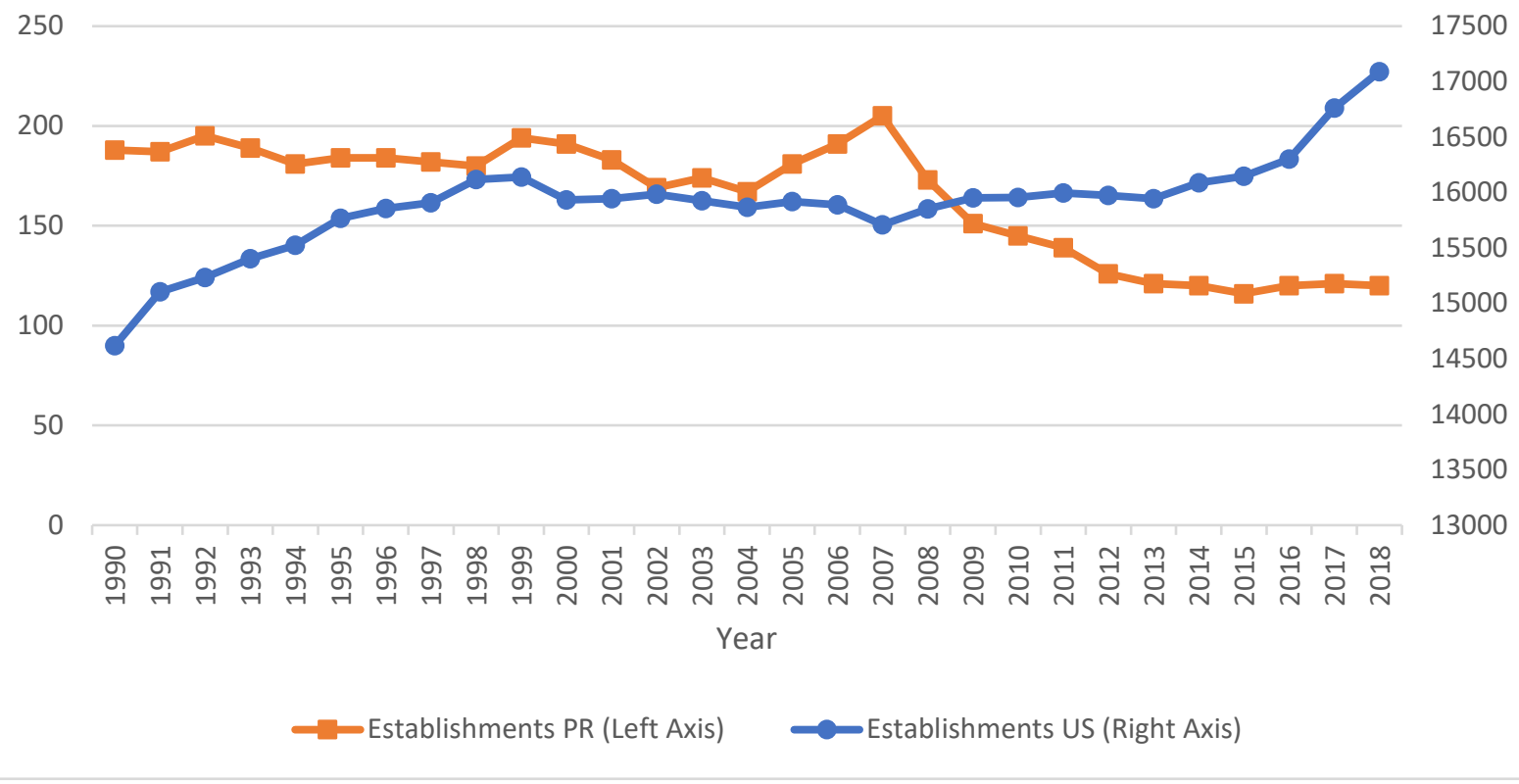

Source: Authors' graph. QCEW public data

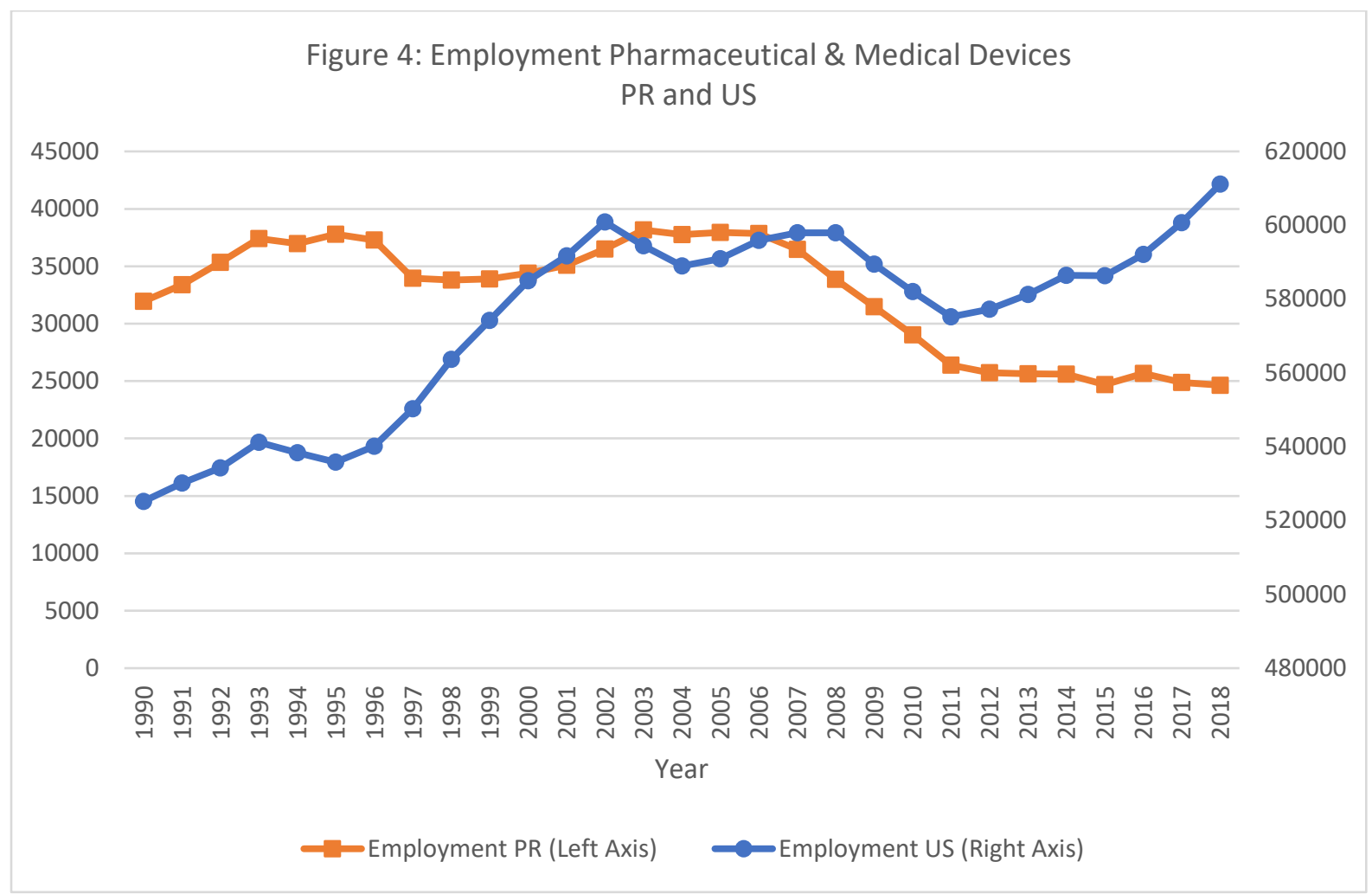

Source: Authors’ graph. QCEW public data 
Figure 5: Change in Employment Within and Between

Pharmaceutical and Medical Devices Establishments
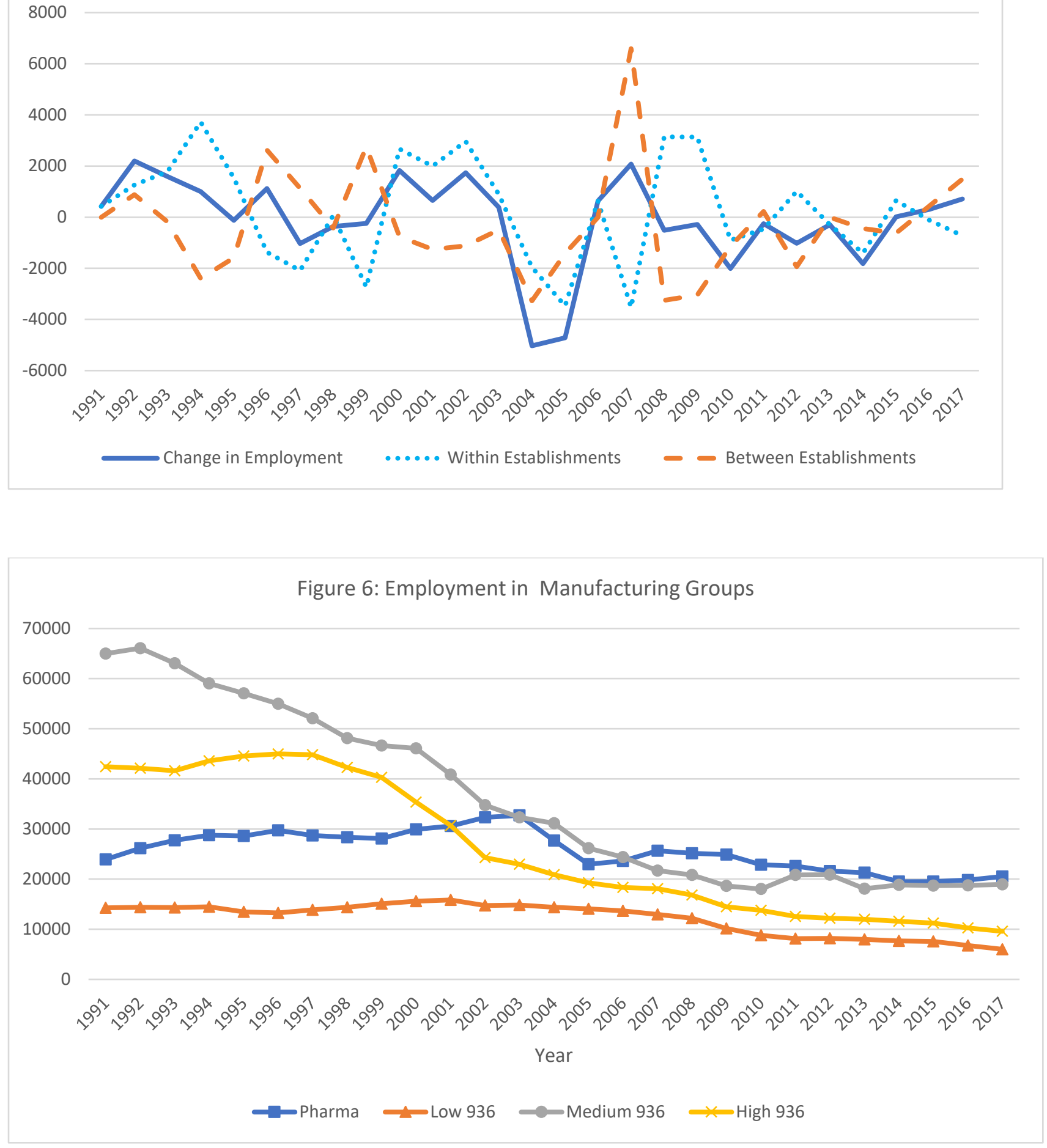


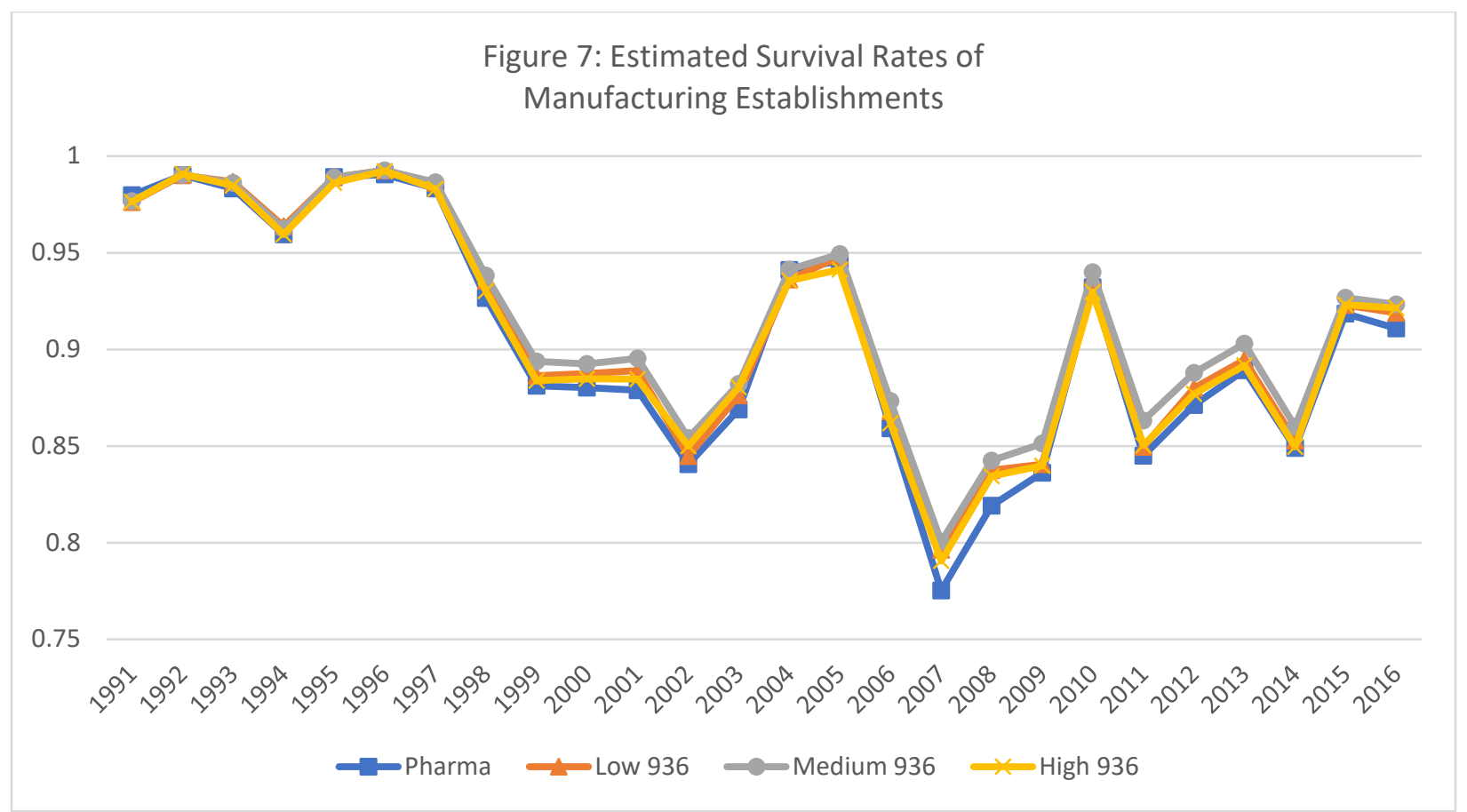


Figure 8: Estimated Annual Survival Rate Differentials

Pharmaceuticals vs Non-Pharma Establishments

95\% Confidence Interval

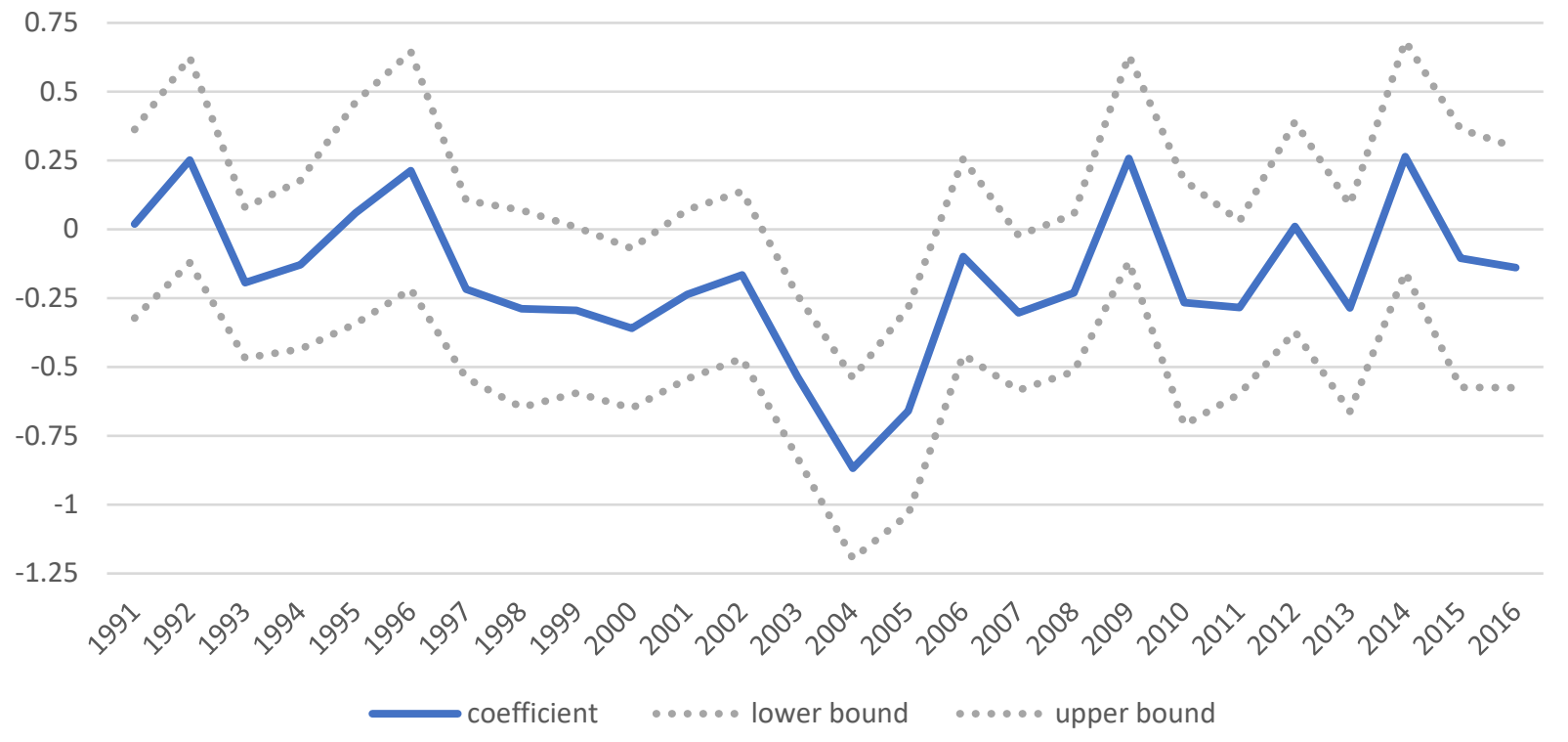

Figure 9: Estimated Annual Employment Differentials

Pharmaceuticals vs Non-Pharma Establishments

95\% Confidence Interval

1

0.8

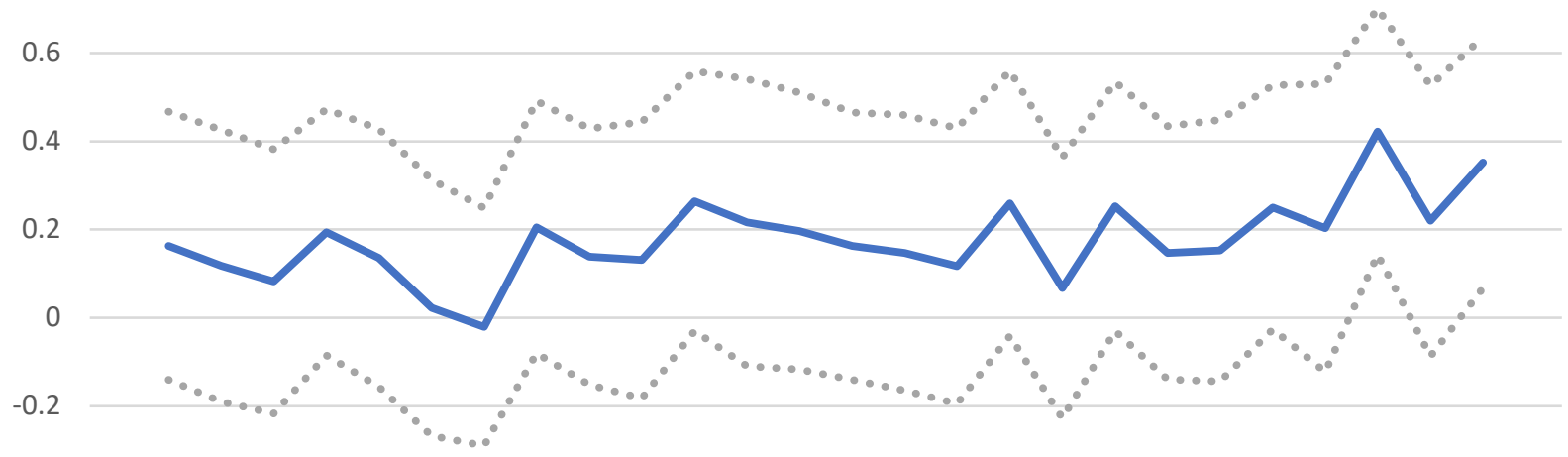

$-0.4$

જે

coefficient $\quad \ldots$ l... lower bound $\quad \ldots$ upper bound 
Table 1: Tax Credits and Employment of IRC Section 936 Corporations

\begin{tabular}{|c|c|c|c|c|c|c|c|c|c|}
\hline \multirow[b]{3}{*}{$\begin{array}{l}\text { All } 936 \\
\text { manufacturing }\end{array}$} & \multicolumn{3}{|c|}{$\begin{array}{c}\text { Estimated Tax Credits } \\
\text { Millions } 2015 \text { USD }\end{array}$} & \multicolumn{3}{|c|}{$\begin{array}{c}\text { Tax Benefits per Employee } \\
2015 \text { USD }\end{array}$} & \multicolumn{3}{|c|}{ Employment } \\
\hline & 1983 & 1989 & 1993 & 1983 & 1989 & 1993 & 1983 & 1989 & 1993 \\
\hline & $\begin{array}{r}\$ 3,524 \\
\text { Perce }\end{array}$ & $\begin{array}{l}\$ 4,071 \\
\text { of } \mathrm{Ta}\end{array}$ & $\begin{array}{l}\$ 6,736 \\
\text { redit }\end{array}$ & $\$ 39,782$ & $\$ 38,579$ & $\$ 33,437$ & 88,579 & 105,511 & 109,598 \\
\hline $\begin{array}{l}\text { Food and kindred } \\
\text { prod }\end{array}$ & 6.9 & 11.4 & 12.6 & 30,031 & 39,105 & 67,435 & 8,098 & 11,828 & 10,136 \\
\hline Textile mill prod & 0.2 & 0.0 & 0.0 & 6,383 & 4,832 & 1,450 & 996 & 329 & 769 \\
\hline Apparel & 3.1 & 1.6 & 1.7 & 7,017 & 3,405 & 4,950 & 15,628 & 19,611 & 19,752 \\
\hline Chemicals & 49.3 & 56.1 & 49.9 & 114,090 & 110,881 & 117,952 & 15,227 & 20,599 & 24,057 \\
\hline Pharmaceuticals & 46.3 & 50.4 & 46.4 & 124,143 & 113,928 & 120,343 & 13,149 & 18,011 & 22,026 \\
\hline Rubber and plastic & 0.7 & 0.8 & 0.2 & 21,680 & 4,910 & 4,223 & 1,173 & 6,475 & 2,373 \\
\hline Leather & 1.0 & 0.5 & 0.5 & 7,745 & 4,983 & 3,545 & 4,720 & 4,466 & 7,621 \\
\hline Fabricated metal & 1.3 & 0.8 & 0.1 & 22,648 & 13,626 & 5,057 & 1,965 & 2,333 & 1,143 \\
\hline $\begin{array}{l}\text { Machinery, except } \\
\text { electrical }\end{array}$ & 1.0 & 4.4 & 1.0 & 43,366 & 53,896 & 24,559 & 843 & 3,303 & 2,500 \\
\hline $\begin{array}{l}\text { Electrical and } \\
\text { electronic equip }\end{array}$ & 23.3 & 13.5 & 22.5 & 32,240 & 25,873 & 75,455 & 25,439 & 21,256 & 17,500 \\
\hline $\begin{array}{l}\text { Instruments and } \\
\text { related prod }\end{array}$ & 7.0 & 7.3 & 9.5 & 19,477 & 34,850 & 32,916 & 12,649 & 8,483 & 16,758 \\
\hline Other manufacturing & 6.1 & 3.6 & 2.0 & 35,384 & 27,200 & 19,674 & 6,109 & 5,376 & 6,989 \\
\hline
\end{tabular}

Source: Based on data from General Accounting Office (1993) and Miller (1999). Tax benefits and wages were adjusted for inflation using the implicit price deflator for U.S. GDP. 


\begin{tabular}{|c|c|c|}
\hline Pharmaceutical Corporation & Drug & $\begin{array}{c}\text { Rank of Drug } \\
\text { US Sales } \\
1990\end{array}$ \\
\hline American Home Products & Premarin & 4 \\
\hline Upjohn & Xanax & 5 \\
\hline SmithKline Beecham & Dyazide & 6 \\
\hline Eli Lilly & Ceclor & 7 \\
\hline Boots & Synthroid & 8 \\
\hline Merck & Vasotec & 9 \\
\hline Marion Merrell Dow & Seldane & 10 \\
\hline ICI Pharmaceuticals & Tenormin & 11 \\
\hline Marion Merrell Dow & Cardizem & 12 \\
\hline Bristol-Myers Squibb & Capoten & 13 \\
\hline Syntex & Naprosyn & 14 \\
\hline SmithKline Beecham & Tagamet & 15 \\
\hline Eli Lilly & Prozac & 16 \\
\hline Monsanto (Searle) & Calan SR & 17 \\
\hline Johnson \& Johnson & Ortho-Novum 7/7/7 & 18 \\
\hline Ciba-Geigy & Lopressor & 19 \\
\hline Warner-Lambert & Dilantin & 21 \\
\hline Johnson \& Johnson & Tylenol w/codeine & 25 \\
\hline Shering-Plough & Theo-Dur & 26 \\
\hline Eli Lilly & Darvocet-N 100 & 27 \\
\hline Upjohn & Micronase & 28 \\
\hline Upjohn & Halcion & 30 \\
\hline Merck & Mevacor & 32 \\
\hline Pfizer & Procardia XL & 33 \\
\hline Upjohn & Povera & 34 \\
\hline Pfizer & Procardia & 35 \\
\hline
\end{tabular}

Source: Based on data from General Accounting Office (1992) 
Table 3: Pharmaceutical Corporations located in Puerto Rico, 1989-2015

\begin{tabular}{|c|c|c|c|}
\hline Name of Firm & $\begin{array}{c}\text { Year } \\
\text { Established } \\
\text { in PR }\end{array}$ & Name of Firm & $\begin{array}{c}\text { Year } \\
\text { Established } \\
\text { in PR }\end{array}$ \\
\hline Becton Dickinson \& Co. & 1956 & Alcon Laboratories Inc. / Novartis & 1974 \\
\hline Baxter International Inc. & 1957 & B. Braun of P.R. Inc. & 1974 \\
\hline Boehringer Ingelheim / Western Fher & 1961 & $\begin{array}{l}\text { Industrial Chemicals Corp. / Omni- } \\
\text { Chem }\end{array}$ & 1974 \\
\hline Johnson and Johnson & 1962 & Kendall McGaw Laboratories & 1974 \\
\hline Warner-Lambert Co. & 1962 & Medtronic Puerto Rico & 1974 \\
\hline Eli Lilly \& Co & 1965 & Wyeth Pharmaceuticals Inc. & 1974 \\
\hline Fenwal International Inc. & 1965 & $\begin{array}{l}\text { Sterling Pharmaceutical, Inc. / } \\
\text { Searle/Monsanto }\end{array}$ & 1974 \\
\hline Forto Chemical Corp. & 1966 & Procter \& Gamble Corp. / Olay Co. & 1974 \\
\hline Praxair Puerto Rico BV & 1966 & $\begin{array}{l}\text { Syntex Corp/Syntex Labs. /Corden } \\
\text { Pharma }\end{array}$ & 1974 \\
\hline Verpas Products Inc. & 1966 & DuPont & 1975 \\
\hline GlaxoSmithKline & 1967 & Max Chemical Inc. & 1975 \\
\hline Ecolab Manufacturing Inc. & 1968 & $\begin{array}{l}\text { USSC Puerto Rico Inc./Covidien/ } \\
\text { Medtronics }\end{array}$ & 1979 \\
\hline $\begin{array}{l}\text { Abbott Pharmaceuticals P.R. } \\
\text { Ltd./Abbvie }\end{array}$ & 1969 & Pall Biomedical Inc. & 1982 \\
\hline Merck \& Co. Inc. & 1969 & Zimmer Biomet / Zimmer Biomet & 1982 \\
\hline Monsanto / Pfizer & 1969 & IPR Pharmaceuticals Inc / AstraZeneca & 1986 \\
\hline Bristol-Myers Co. Squibb & 1970 & Patheon Inc. & 1986 \\
\hline Schering-Plough Corp. & 1970 & St.Jude Medical P.R. B.V. & 1988 \\
\hline $\begin{array}{l}\text { F. Hoffman-La Roche \& Co /Roche } \\
\text { Holding AG. }\end{array}$ & 1971 & Stryker Puerto Rico & 1988 \\
\hline Edwards Lifesciences Technology Sarl & 1972 & Boston Scientific Puerto Rico & 1989 \\
\hline Rhone-Poulenc Rorer /Sanofi SA & 1972 & Amgen Manufacturing Ltd. & 1992 \\
\hline Pfzer & 1973 & Neolpharma Inc. & 2012 \\
\hline
\end{tabular}

Source: Authors’ tabulations. Data from Caribbean Business, Book of Lists, 1990-2017. 
Table 4: Firm Classification by Industry Groups

\begin{tabular}{|c|l|c|c|}
\hline SIC & \multicolumn{1}{|c|}{ Industry Description } & $\begin{array}{c}\text { Production by } \\
936 \text { firms (\%) }\end{array}$ & Type \\
\hline 28 \& 384-385 & Chemicals, Pharmaceuticals \& Medical Devices & 99.6 & Pharma \\
24 & Lumber and wood products & 3.4 & Low \\
25 & Furniture and fixtures & 3.4 & Low \\
27 & Printing and publishing & 9.0 & Low \\
32 & Stone, clay, and glass & 11.8 & Low \\
34 & Fabricated metal products & 32.2 & Medium \\
26 & Paper and allied products & 44.8 & Medium \\
30 & Rubber and miscellaneous & 70.4 & Medium \\
20 & Food and kindred products & 72.6 & Medium \\
23 & Apparel and other textile products & 77.6 & Medium \\
33 & Primary metal industrial products & 83 & High \\
37 & Transportation equipment & 84.7 & High \\
39 & Miscellaneous manufacturing & 87.5 & High \\
22 & Textile mill products & 91.0 & High \\
31 & Leather and leather products & 93.6 & High \\
29 & Petroleum and coal products & 94.6 & High \\
36 & Electronic and other & 96.2 & High \\
38 & Instruments and related & 96.9 & High \\
35 & Industrial machinery & 97.8 & High \\
21 & Tobacco products & 99.3 & High \\
\hline
\end{tabular}

Source: Authors’ calculation. Data from Puerto Rico Planning Board (1993) for 1987. 
Table 5: Probit Survival Rate Model of Pharmaceutical and Medical Devices in Puerto Rico

\begin{tabular}{|c|c|c|c|c|}
\hline $\begin{array}{l}\text { Independent } \\
\text { Variables }\end{array}$ & $\begin{array}{c}\text { Survival Pharma } \\
\text { Control } \\
\text { Low } 936\end{array}$ & $\begin{array}{c}\text { Survival Pharma } \\
\text { Control } \\
\text { Medium } 936\end{array}$ & $\begin{array}{c}\text { Survival Pharma } \\
\text { Control } \\
\text { High } 936\end{array}$ & $\begin{array}{c}\text { Survival Pharma } \\
\text { Control } \\
\text { Non-Pharma }\end{array}$ \\
\hline $\begin{array}{l}\text { Lag } \\
\text { Employment }\end{array}$ & $\begin{array}{l}.254^{* * *} \\
(.013)\end{array}$ & $\begin{array}{l}.187 * * \\
(.011)\end{array}$ & $\begin{array}{c}.179^{* * *} \\
(.015)\end{array}$ & $\begin{array}{l}.218^{* *} \\
(.008)\end{array}$ \\
\hline Age & $\begin{array}{c}.005^{* * *} \\
(.002)\end{array}$ & $\begin{array}{c}.002 \\
(.002)\end{array}$ & $\begin{array}{c}.003 \\
(.002)\end{array}$ & $\begin{array}{c}.005^{* * *} \\
(.001)\end{array}$ \\
\hline San Juan Metro & $\begin{array}{c}.004 \\
(.032)\end{array}$ & $\begin{array}{l}.072^{* *} \\
(.031)\end{array}$ & $\begin{array}{c}0.147 * * * \\
(.040)\end{array}$ & $\begin{array}{l}.043^{* *} \\
(.020)\end{array}$ \\
\hline $\begin{array}{l}\text { Large } \\
\text { Establishment }\end{array}$ & $\begin{array}{c}-.558 * * * \\
(.089)\end{array}$ & $\begin{array}{c}-.314^{* * *} \\
(.068)\end{array}$ & $\begin{array}{c}-.266 * * * \\
(.083)\end{array}$ & $\begin{array}{c}-.471^{* * *} \\
(.052)\end{array}$ \\
\hline 936 Phaseout & $\begin{array}{r}-.201 \\
(.168)\end{array}$ & $\begin{array}{c}-.293^{* *} \\
(.148)\end{array}$ & $\begin{array}{l}-.093 \\
(.168)\end{array}$ & $\begin{array}{l}-.163 * \\
(.098)\end{array}$ \\
\hline After 936 & $\begin{array}{c}-.673^{* * * *} \\
(.171)\end{array}$ & $\begin{array}{c}-.404^{* * *} \\
(.152)\end{array}$ & $\begin{array}{l}-.354 * * \\
(.171)\end{array}$ & $\begin{array}{c}-.468 * * * \\
(.099)\end{array}$ \\
\hline $\begin{array}{l}\text { Pharma x } \\
936 \text { Phaseout }\end{array}$ & $\begin{array}{c}-.490 * * * \\
(.070)\end{array}$ & $\begin{array}{c}-.324^{* * *} \\
(.063)\end{array}$ & $\begin{array}{c}-.295 * * * \\
(.066)\end{array}$ & $\begin{array}{c}-.362 * * * \\
(.060)\end{array}$ \\
\hline $\begin{array}{l}\text { Pharma x } \\
\text { After } 936\end{array}$ & $\begin{array}{l}-.150 * * \\
(.068)\end{array}$ & $\begin{array}{l}-.125^{* *} \\
(.060)\end{array}$ & $\begin{array}{l}-.068 \\
(.063)\end{array}$ & $\begin{array}{l}-.111^{*} \\
(.059)\end{array}$ \\
\hline $\begin{array}{l}\text { Industry } \\
\text { Dummies }\end{array}$ & Yes & Yes & Yes & Yes \\
\hline Observations & 17,418 & 19,673 & 11,932 & 43,987 \\
\hline R-Squared & 0.14 & 0.11 & 0.11 & 0.12 \\
\hline
\end{tabular}

Note: * Significant $10 \%$ level, ${ }^{* *}$ Significant $5 \%$ level, *** Significant $1 \%$ 
Table 6: Marginal impact of eliminating IRC Section 936 on Survival of Pharmaceutical and Medical Devices.

\begin{tabular}{|l|c|c|c|c|}
\hline & \multicolumn{4}{|c|}{ Control Groups } \\
\hline Estimated Marginal Probabilities & Low 936 & Medium 936 & High 936 & Non-Pharma \\
\hline 936 Phaseout & -.030 & $-.043^{* *}$ & -.014 & $-.024^{*}$ \\
After 936 & $-.101^{* * *}$ & $-.059^{* * *}$ & $-.053^{* *}$ & $-.069^{* * *}$ \\
Pharma x 936 Phaseout & $-.073^{* * *}$ & $-.047^{* * *}$ & $-.044^{* * *}$ & $-.053^{* * *}$ \\
Pharma x After 936 & $-0.022^{* *}$ & $-0.018^{* *}$ & -.010 & $-0.016^{*}$ \\
& & & & -0.162 \\
\hline
\end{tabular}

Note: * Significant 10\% level, ** Significant 5\% level, *** Significant 1\% 
Table 7: Fixed Effects Model of Employment in Pharmaceutical and Medical Devices in Puerto Rico

\begin{tabular}{|l|c|c|c|c|}
\hline $\begin{array}{l}\text { Independent } \\
\text { Variables }\end{array}$ & $\begin{array}{c}\text { Employment } \\
\text { Control } \\
\text { Low 936 }\end{array}$ & $\begin{array}{c}\text { Employment } \\
\text { Control } \\
\text { Medium 936 }\end{array}$ & $\begin{array}{c}\text { Employment } \\
\text { Control } \\
\text { High 936 }\end{array}$ & $\begin{array}{c}\text { Employment } \\
\text { Control } \\
\text { Non-Pharma }\end{array}$ \\
\hline Survival Rate & $3.589^{* * *}$ & $4.316^{* * *}$ & $3.949^{* * *}$ & $\begin{array}{c}.036^{* * *} \\
(.122)\end{array}$ \\
San Juan Metro & $(.179)$ & $(.192)$ & .081 & .028 \\
Large & -.034 & .131 & $(.076)$ & $(.064)$ \\
Establishment & $(.110)$ & $(.090)$ & $2.102^{* * *}$ & $1.812^{* * *}$ \\
& $(.147)$ & $1.740^{* * *}$ & $(.129)$ & $(.085)$ \\
936 Phaseout & .004 & $(.114)$ & $-.077 * *$ & $-.029 *$ \\
After 936 & $(.025)$ & -.037 & $(.036)$ & $(.016)$ \\
Pharma x & $-.121^{* * *}$ & $-.161^{* * * *}$ & $-.200^{* * *}$ & $-.148^{* * *}$ \\
936 Phaseout & $(.037)$ & $(.034)$ & $(.048)$ & $(.022)$ \\
Pharma x & -.049 & .027 & .066 & .031 \\
After 936 & $(.085)$ & $(.080)$ & $(.087)$ & $(.074)$ \\
\hline Observations & -.037 & .076 & .122 & .081 \\
\hline R-Squared & $(.107)$ & $(.100)$ & $(.109)$ & $(.091)$ \\
\hline
\end{tabular}

Note: * Significant 10\% level, ** Significant 5\% level, *** Significant $1 \%$ 
Table 8: Test of pre-trends in employment of pharmaceutical and medical devices and control groups, 1990 to 1994.

\begin{tabular}{|l|c|c|}
\hline $\begin{array}{l}\text { Pre-Trend Pharmaceuticals and } \\
\text { Medical Devices }\end{array}$ & P-Value & $\begin{array}{c}\text { Result } \\
\text { Rejection at the 5\% level }\end{array}$ \\
\hline Low 936 & $\begin{array}{c}\mathrm{F}(5,1865)=1.21 \\
\mathrm{P} \text {-value }=.304\end{array}$ & Do not Reject \\
\hline Medium 936 & $\begin{array}{c}\mathrm{F}(5,2320)=2.84 \\
\mathrm{P} \text {-value }=.015\end{array}$ & Reject \\
\hline High 936 & $\begin{array}{c}\mathrm{F}(5,975)=1.27 \\
\text { P-value }=.274\end{array}$ & Do not Reject \\
\hline $\begin{array}{l}\text { Non-Pharma } \\
\text { Manufacturing }\end{array}$ & $\begin{array}{c}\mathrm{F}(5,4207)=1.43 \\
\text { P-value }=.209\end{array}$ & Do not Reject \\
\hline
\end{tabular}

Note: * Significant 10\% level, ** Significant 5\% level, *** Significant $1 \%$ 